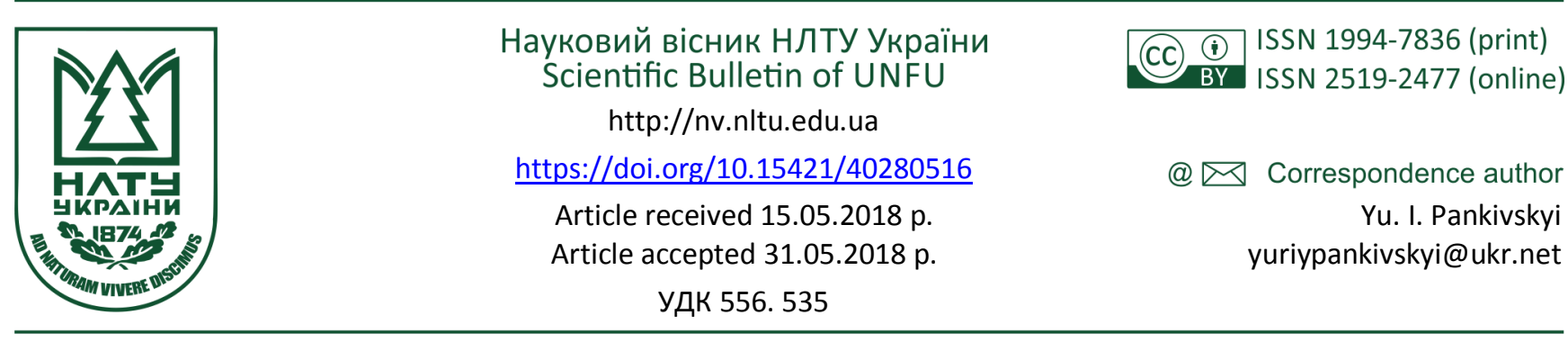

Ю. І. Панківський, О. Є. Ошуркевич-Панківська

Національний лісотехнічний університет Украйни, м. Львів, Украйна

\title{
ОЦІНЮВАННЯ ВПЛИВУ ВОДОКАНАЛІЗАЦІЙНОГО ГОСПОДАРСТВА МІСТА МОСТИСЬКА НА ЯКІСТЬ ВОДИ У РІЧЦІ ВИШНЯ
}

\begin{abstract}
Для оцінювання впливу каналізаційних очисних споруд міста Мостиська на річку Вишня розрахунковими методами визначено мінімальні розрахункові витрати води за лімітуючими сезонами року; на основі заміряних морфометричних характеристик русла розраховано швидкість руху води у річці; проведено гідрохімічні дослідження зворотних вод очисних споруд на випуску та природних вод у фоновому створі вище випуску і у розрахунковому створі нижче випуску; для літньоосінньої та зимової межені на основі гідроморфометричних характеристик русла розраховано кратність розведення зворотних вод природними; за допомогою комп'ютерної програми "Гідросфера" спрогнозовано концентрації забруднювальних речовин у розрахунковому створі при фактичному скиді у лімітуючі сезони року з використанням математичної моделі динаміки концентрації речовини у водотоці; для визначення асиміляційної здатності річки-приймача зворотних вод виконано розрахунок максимальних допустимих концентрацій забруднювачів до скиду у водний об'єкт за лімітуючими сезонами року за умови досягнення гранично допустимої, або фонової концентрації у розрахунковому створі. Встановлено, що природний водний об'єкт здатний асимілювати забруднення в обсягах, що у кілька разів, а за окремими показниками у десятки разів, перевищують фактичний скид. Проте за основним забруднювачем - органікою, асиміляційна здатність річки вичерпана повністю.
\end{abstract} ність.

Ключові слова: випуск; фоновий ствір; розрахунковий ствір; зворотні води; кратність розведення; асиміляційна здат-

Вступ. Дані моніторингу якості поверхневих вод Львівщини свідчать про те, що незважаючи на значний спад промислового виробництва, за останні роки простежується тенденція до погіршення екологічного стану поверхневих водойм (Oshurkevych-Pankivska, et al., 2015) як за санітарно-хімічними, так і мікробіологічними показниками. Основною причиною незадовільної якості природних вод $\epsilon$ забруднення поверхневих водойм скидами неочищених стічних і недостатньо очищених зворотних вод. Найвідчутніше на це реагують невеликі водні об'єкти - малі річки, що розташовані в умовах одного ландшафту і мають невеликі витрати води, а результативна дія природних та антропогенних факторів на них проявляється швидше i виразніше (Khimko, Merezhko \& Babko, 2003). Малі річки формують водні ресурси, гідрохімічний режим та якість води у середніх та великих річках, створюють умови для формування на площах їх водозборів відповідних ландшафтів і водночас, зазвичай, вони стають головними приймачами зворотних вод об'єктів господарювання. Найгірша ситуація з очищення стічних вод спостерігається у невеликих містах, містечках, селищах, де очисні споруди внаслідок фізичної зношеності $\epsilon$ неефективними, а подекуди й просто відсутні.
3 огляду на це актуальними є дослідження з оцінювання впливу об'єктів господарювання на стан поверхневих водойм.

Мета роботи - оцінити вплив каналізаційних очисних споруд міста Мостиська на річку Вишня - приймача зворотних вод.

Об'єкт дослідження. Місто Мостиська є районним центром Львівської обл. з населенням 9044 особи. Основними джерелами утворення стічних вод у місті $\epsilon$ житлові будинки, державні та громадські установи, господарсько-побутові стоки яких містять багато завислих речовин, сечовини, фекальних мас, синтетичні мийні засоби; атмосферні стічні води, що надходять 3 поверхневим стоком із житлової забудови, автомобільних стоянок, гаражів, доріг та містять завислі домішки, мінеральні та органічні речовини, нафтопродукти. Стічні води надходять у міську загальносплавну каналізацію господарсько-побутових і виробничих стоків. Фактичне надходження стічних вод на очищення згідно з матеріалами (Vodokorystuvannia, 2005) дорівнює $671,76 \mathrm{~m}^{3} /$ добу, $27,99 \mathrm{~m}^{3} /$ год, 245,2 тис. ${ }^{3} /$ рік.

Майданчик очисних споруд розташований на лівому березі р. Вишня на відстані 1,7 км на північний захід від межі міста. Проектна потужність каналізаційних очисних споруд (КОС) становить $1460 \mathrm{~m}^{3} /$ добу,

\section{Інформація про авторів:}

Панківський Юрій Іванович, канд. фіз.-мат. наук, доцент, кафедра екологіï. Email: yuriypankivskyi@ukr.net

Ошуркевич-Панківська Оксана Євгенівна, канд. с.-г. наук, ст. викладач, кафедра екологіï. Email: oxosh@ukr.net

Цитування за ДСтУ: Панківський Ю. І., Ошуркевич-Панківська О. Є. Оцінювання впливу водоканалізаційного господарства міста Мостиська на якість води у річці Вишня. Науковий вісник НлТУ України. 2018, т. 28, № 5. С. 74-77.

Citation APA: Pankivskyi, Yu. I., \& Oshurkevych-Pankivska, O. Ye. (2018). Impact assesment of the waste water treatment facilities of Mostyska town on the water quality of the Vyshnya river. Scientific Bulletin of UNFU, 28(5), 74-77.

https://doi.org/10.15421/40280516 
532,9 тис. м³/рік (Kanalizatsiia, 1989). До їх складу входять: решітки, пісколовки, первинні відстійники, аеротенки, вторинні відстійники, контактні резервуари, мулові майданчики, біостави. КОС м. Мостиська прийняті за технологічною схемою повного біохімічного очищення 3 доочищенням у біоставах. Згідно з вимогами нормативних документів (Instruktsiia, 1994; Kanalizatsiia, 1989) після основного очищення вміст БСК у зворотних водах не має перевищувати 15 мг/л, а після доочищення у біоставах -4 мг/л.

Знезаражені зворотні води КОС в об'ємі 245,2 тис. $\mathrm{m}^{3} /$ piк (Vodokorystuvannia, 2005) закритим колектором скидаються у Вишню. Річка Вишня бере свій початок на північному заході с. Мокряни на висоті 225 м н. р. м. i впадає в р. Сян 3 правого берега на 137-му кілометрі від гирла.

Результати дослідження та їх обговорення. Оскільки Вишня належить до річок, недостатньо вивчених у гідрологічному плані, то мінімальні 30 -добові витрати води для лімітуючих сезонів року визначали розрахунковим методом (Gidrologiia, 1984). Спочатку розрахували мінімальні 30-добові витрати води забезпеченості 80 \% у літньо-осінній та зимовий періоди, а потім визначили розрахункову витрату $\mathrm{Q}_{95}$ (табл. 1). Як бачимо, найменші витрати води у Вишні простежуються у зимовий період, коли припиняється живлення річки дощовими і талими водами.

Табл. 1. Мінімальні витрати води у р. Вишня у меженні періоди

\begin{tabular}{|l|c|c|}
\hline \multirow{2}{*}{ Період } & \multicolumn{2}{|c|}{ Витрата води, $\mathrm{M}^{3} / \mathrm{c}$} \\
\cline { 2 - 3 } & $\mathrm{Q}_{80 \%}$ & $\mathrm{Q}_{95 \%}$ \\
\hline Літньо-осіння межень & 0,40 & 0,30 \\
\hline Зимова межень & 0,38 & 0,21 \\
\hline
\end{tabular}

На основі заміряних морфометричних характеристик русла (ширини та глибин) розрахували площу живого перерізу русла $\omega$, а потім швидкість руху води у річці. Під час літньо-осінньої межені швидкість руху води у річці становить $0,05 \mathrm{~m} / \mathrm{c}$, а під час зимової$0,04 \mathrm{M} / \mathrm{c}$.

Для оцінювання впливу каналізаційних очисних споруд на якість води у Вишні проведено гідрохімічні дослідження зворотних вод КОС на випуску (табл. 2) та природних вод у фоновому створі (50 м вище випуску зворотних вод) i у розрахунковому (контрольному) створі (300 м нижче випуску) (табл. 3). Відбір проб води та аналітичні дослідження параметрів іiї якості виконано за стандартизованими методиками згідно 3 (Lenore, et al., 1998).

Табл. 2. Якісна характеристика зворотних вод на випуску

\begin{tabular}{|c|c|c|}
\hline № 3/ח & Показник & Концентрація, мг/л \\
\hline 1 & Температура & 15,0 \\
\hline 2 & $\mathrm{pH}$ & 7,8 \\
\hline 3 & Завислі речовини & 15,0 \\
\hline 4 & БСК & 19,81 \\
\hline 5 & $\mathrm{BCK}_{5}$ & 14,9 \\
\hline 6 & СПАР & 0,8 \\
\hline 7 & Азот амонійний & 1,0 \\
\hline 8 & Залізо (загальне) & 0,26 \\
\hline 9 & Нітрати & 23,43 \\
\hline 10 & Нітрити & 0,38 \\
\hline 11 & Сульфати & 100,2 \\
\hline 12 & Фосфати & 2,4 \\
\hline 13 & Хлориди & 204,0 \\
\hline
\end{tabular}

Результати дослідження якості зворотних вод на випуску (див. табл. 2) показують, що за основним забруднювачем (БСК ламентного значення 4 мг/л.

Якість води Вишні у фоновому створі (див. табл. 3) характеризується завищеним вмістом органічних речовин - 2,3 ГДК і заліза - 2,5 ГДК і нітритів - 2,3 ГДК, що загалом узгоджується 3 даними моніторингу поверхневих вод Львівщини. Завищений вміст БСК та нітритів, очевидно, спричинений постійним довготривалим надходженням органіки у річку зі сільськогосподарських угідь.

Результати аналізів проб води у контрольному ствоpi нижче випуску з КОС м. Мостиська, вказують на те, що зворотні води загалом неістотно знижують якість води у Вишні, хоч простежується незначне перевищення фонових значень за основними показниками. 3 огляду на це можна стверджувати, що на розрахунковій ділянці річки відбувається повне змішування зворотних вод КОС з річковими.

Табл. 3. Гідрохімічна характеристика водного об'сктуприймача зворотних вод річки Вишня

\begin{tabular}{|c|c|c|c|c|}
\hline \multirow{2}{*}{$\begin{array}{l}\text { № } \\
\text { 3/ח }\end{array}$} & \multirow[b]{2}{*}{ Показник } & \multirow{2}{*}{$\begin{array}{c}\Gamma Д К_{\mathrm{p} / \mathrm{r}}, \\
\text { мг/л }\end{array}$} & \multicolumn{2}{|c|}{ Концентрація, мг/л } \\
\hline & & & $\begin{array}{c}\text { фоновий } \\
\text { ствір }\end{array}$ & $\begin{array}{c}\text { контрольний } \\
\text { ствір }\end{array}$ \\
\hline 1 & Температура & - & 14,00 & 14,00 \\
\hline 2 & $\mathrm{pH}$ & $6,5-8,5$ & 7,50 & 7,50 \\
\hline 3 & Завислі речовини & $\phi+0,75$ & 15,00 & 15,60 \\
\hline 4 & БСК повн & 3,00 & 7,10 & 7,32 \\
\hline 5 & $\mathrm{BCK}_{5}$ & 2,26 & 5,33 & 5,63 \\
\hline 6 & СПАР & 0,10 & 0,01 & 0,02 \\
\hline 7 & Азот амонійний & 0,39 & 0,24 & 0,28 \\
\hline 8 & Залізо (загальне) & 0,10 & 0,25 & 0,25 \\
\hline 9 & Нітрати & 40,0 & 11,00 & 12,80 \\
\hline 10 & Нітрити & 0,08 & 0,19 & 0,10 \\
\hline 11 & Сульфати & 100,0 & 59,00 & 75,00 \\
\hline 12 & Фосфати & 3,12 & 1,41 & 1,58 \\
\hline 13 & Хлориди & 300,0 & 36,40 & 44,50 \\
\hline
\end{tabular}

Головними параметрами, які визначають інтенсивність процесу розведення зворотних вод на випуску у природні водні об'єкти, є кратність початкового та основного розведення. Початкове розведення залежить від умов випуску зворотних вод. За безнапірних умов (v $<2$ м/с), як у нашому випадку, кратність початкового розведення приймаємо $\mathrm{n}_{\text {поч }}=1$. А кратність основного розведення, розрахована на основі гідроморфометричних характеристик русла, для літньо-осінньої межені дорівнює $\mathrm{n}_{\text {осн }}=32,52$, а для зимової $-\mathrm{n}_{\text {осн }}=23,07$. Оскільки взимку витрата води у Вишні є значно меншою, ніж влітку (чи восени), то й кратність розбавлення взимку майже в 1,5 раза менша.

Враховуючи розведення зворотних вод річковими, згідно з методикою (Instruktsiia, 1994), за допомогою комп'ютерної програми "Гідросфера" спрогнозовано концентрації забруднювальних речовин у розрахунковому створі при фактичному скиді у лімітуючі сезони року з використанням математичної моделі динаміки концентрації речовини у водотоці:

$$
C(t)=\left(C_{0}-C_{\phi}\right) \cdot e^{-k t}+C_{\phi},
$$

де: $C_{0}, C(t)$ - концентрації речовини у початковий момент і в момент часу $t$; $C_{\phi}$ - природна фонова концентрація речовини; $k$ - коефіцієнт не консервативності речовини, що характеризує інтенсивність процесу самоочищення. 
Як бачимо (табл. 4), у контрольному-розрахунковому створі концентрації більшості забруднювальних речовин повертаються до свого фонового значення, лише за БСК маємо незначне перевищення. Концентрації таких речовин, як СПАРи та нітрити навіть не перевищують ГДК для водойм рибогосподарської категорії користування. Загалом прогнозовані концентрації узгоджуються з результатами аналітичних вимірювань. Треба зазначити, що взимку процеси біодеградації відбува- ються повільніше, про що свідчать більші значення концентрацій забруднювальних речовин у зимовий період порівняно з літнім.

Для визначення асиміляційної здатності річкиприймача зворотних вод виконано розрахунок максимальних допустимих концентрацій забруднювачів до скиду у водний об'єкт за лімітуючими сезонами року за умови досягнення гранично допустимої, або фонової концентрації у контрольному створі (табл. 5).

Табл. 4. Прогнозовані концентрації забруднювачів у розрахунковому створі при фактичному скиді

\begin{tabular}{|c|c|c|c|c|c|c|}
\hline \multirow{2}{*}{$\begin{array}{c}\text { № } \\
3 / \text { п }\end{array}$} & Показник & \multirow{2}{*}{ ГДК } & \multicolumn{2}{|c}{ Фактична концентрація, мг/л } & $\begin{array}{c}\text { Розрахована концентрація у розрахунково- } \\
\text { му створі, мг/л }\end{array}$ \\
\cline { 5 - 7 } & & & фоновий ствір & $\begin{array}{c}\text { розрахунковий } \\
\text { ствір }\end{array}$ & $\begin{array}{c}\text { літньо-осіння ме- } \\
\text { жень }\end{array}$ & зимова межень \\
\hline 1 & Завислі речовини & 15,75 & 15,00 & 15,60 & 15,00 & 15,00 \\
\hline 2 & БСК повн & 3,00 & 7,10 & 7,32 & 7,11 & 7,43 \\
\hline 3 & БСК $_{4}$ & 2,26 & 5,33 & 5,63 & 5,35 & 5,59 \\
\hline 5 & СПАР & 0,10 & 0,01 & 0,02 & 0,03 & 0,04 \\
\hline 6 & Азот амонійний & 0,39 & 0,24 & 0,28 & 0,25 & 0,26 \\
\hline 7 & Залізо загальне & 0,10 & 0,25 & 0,25 & 0,24 & 0,25 \\
\hline 8 & Нітрати & 40,00 & 11,00 & 12,80 & 10,21 & 10,48 \\
\hline 9 & Нітрити & 0,08 & 0,19 & 0,10 & 0,03 & 0,08 \\
\hline 10 & Сульфати & 100,0 & 59,00 & 75,00 & 59,04 & 60,11 \\
\hline 11 & Фосфати & 3,12 & 1,41 & 1,58 & 1,44 & 1,46 \\
\hline
\end{tabular}

Табл. 5. Максимальні допустимі концентрацій до скиду у водний об'єкт

\begin{tabular}{|c|c|c|c|c|}
\hline \multirow{2}{*}{ № 3/п } & \multirow{2}{*}{ Показник } & Фактична концентрація на випуску, & мг/л & Максимально допустима концентрація, мг/л \\
\cline { 3 - 5 } & & 15,00 & літньо-осіння межень & зимова межень \\
\hline 1 & Завислі речовини & $\mathbf{1 9 , 8 1}$ & 40,00 & 32,58 \\
\hline 2 & БСК повне & 14,90 & 16,80 & 10,41 \\
\hline 3 & БСК & 0,80 & 12,68 & 7,85 \\
\hline 4 & СПАР & 1,00 & 3,12 & 2,20 \\
\hline 5 & Азот амонійний & 0,26 & 0,78 & 4,10 \\
\hline 6 & Залізо загальне & 23,43 & 1007,20 & 0,46 \\
\hline 7 & Нітрати & 0,38 & 8,47 & 709,40 \\
\hline 8 & Нітрити & 100,20 & 1451,00 & 0,71 \\
\hline 9 & Сульфати & 2,40 & 57,35 & 1026,60 \\
\hline 10 & Фосфати & 204,00 & 8611,68 & 40,91 \\
\hline 11 & Хлориди & & 6118,18 \\
\hline
\end{tabular}

Отже, максимально допустимі до скиду концентрації залежать від сезону року - влітку вони вищі, внаслідок більшої водності і вищої температури у цей період. За умови досягнення ГДК у розрахунковому створі максимально допустима концентрація завислих речовин вища за фактичну у 2,2 раза взимку та у 2,7 раза влітку, СПАР - у 2,8 та у 3,9 раза, азоту амонійного - у 4,1 та у 5,8 раза, нітратів - у 30,3 та у 43 раза, нітритів - в 1,9 та у 22,3 раза, сульфатів - у 10,2 та у 14,5 раза, фосфатів у 17 та у 24 раза, хлоридів - у 30,0 та у 42,2 раза відповідно.

Висновки. Отже, природний водний об'єкт здатний асимілювати забруднення в обсягах, що у кілька разів, а за окремими показниками у десятки разів, перевищують фактичний скид. Проте за основним забруднювачем - органікою, вираженою в БСК, асиміляційна здатність водного об'єкта вичерпана повністю, більше того, фактичний скид майже у два рази перевищує максимально допустимий. 3 погляду раціонального природокористування повне використання асиміляційної здатності водного об'єкта є неприпустимим, тому під час розроблення проектів ГДС доцільно використовувати типові показники ефективності роботи очисних споруд, зазначені в регламенті. 3 огляду на це для досягнення ГДС навіть за умови збереження фону концентрацію
БСК у зворотних водах КОС м. Мостиська потрібно зменшити майже вдвічі, для чого потрібно інтенсифікувати роботу цеху біохімічного очищення.

\section{Перелік використаних джерел}

Gidrologiia. (1984). Posobie po opredeleniiu raschetnykh gidrologicheskikh kharakteristik. Leningrad: Gidrometeoizdat. 448 p. [In Russian].

Instruktsiia. (1994). Instruktsiia pro poriadok rozrobky ta zatverdzhennia hranychno dopustymykh skydiv (HDS) rechovyn u vodni obiekty zi zvorotnymy vodamy. Kharkiv: UkrNTsOV, YuNYTYeP. 61 p. [In Ukrainian].

Kanalizatsiia. (1989). Tekhnolohichnyi rehlament roboty kanalizatsiinykh ochysnykh sporud m. Mostyska. 77 p. [In Ukrainian].

Khimko, R. V., Merezhko, O. I., \& Babko, R. V. (2003). Mali richky - doslidzhennia, okhorona, vidnovlennia. Kyiv: Instytut ekolohii. 380 p. [In Ukrainian].

Lenore, S., Clesceri (Ed.), Arnold, E., Greenberg, \& Andrew, D., Eaton. (1998). Standard Methods for the Examination of Water and WasteWater. (20th ed.). Washington: APHA, AWWA, WEF. 1085 p.

Oshurkevych-Pankivska, O. Ye., Pankivskyi, Yu. I., \& Vyshyvanyi, O. A. (2015). Otsiniuvannia yakosti poverkhnevykh vod richok Lvivshchyny. Scientific Bulletin of UNFU, 24(3), 94-101. [In Ukrainian].

Vodokorystuvannia. (2005). Dozvil na spetsialne vodokorystuvannia № Ukr-702-05/Lv. Mostyske PVKH. Derzhavne upravlinnia ekolohii ta pryrodnykh resursiv u Lvivskii oblasti. Lviv. 21 p. [In Ukrainian]. 
Ю. И. Панкивский, О. Е. Ошуркевич-Панкивская

Национальный лесотехнический университет Украины, г. Львов, Украина

\section{ОЦЕНКА ВЛИЯНИЯ ВОДОКАНАЛИЗАЦИОННОГО ХОЗЯЙСТВА ГОРОДА МОСТИСКА НА КАЧЕСТВО ВОДЫ В РЕКЕ ВИШНЯ}

С целью оценки влияния канализационных очистных сооружений города Мостиска на реку Вишня расчетными метода-
ми определены минимальные расчетные расходы воды по лимитирующим сезонам года; на основе измеренных морфомет-
рических характеристик русла рассчитана скорость движения воды в реке; проведены гидрохимические исследования об-
ратных вод очистных сооружений на выпуске и природных вод в фоновом створе выше выпуска и в расчетном створе ниже
выпуска; для летне-осенней и зимней межени на основе гидроморфометрических характеристик русла рассчитана кратность
разбавления сточных вод природными; с помощью компьютерной программы "Гидросфера" спрогнозированы концентра-
ции загрязняющих веществ в расчетном створе при фактическом сбросе в лимитирующие сезоны года с использованием ма-
тематической модели динамики концентрации вещества в водотоке; для определения ассимилирующей способности реки-
приемника сточных вод выполнен расчет максимальных допустимых концентраций загрязнителей к сбросу в водный объект
по лимитирующих сезонам года при условии достижения предельно допустимой или фоновой концентрации в расчетном
створе. Установлено, что природный водный объект способен ассимилировать загрязнения в объемах в несколько раз, а по
отдельным показателям в десятки раз превышающим фактический сброс. Однако по основному загрязнителю- органике,
ассимилирующая способность реки исчерпана полностью.
Ключевые слова: выпуск; фоновый створ; расчетный створ; обратные воды; кратность разведения; ассимилирующая способность.

Yu. I. Pankivskyi, O. Ye. Oshurkevych-Pankivska

Ukrainian National Forestry University, Lviv, Ukraine

\section{IMPACT ASSESMENT OF THE WASTE WATER TREATMENT FACILITIES OF MOSTYSKA TOWN ON THE WATER QUALITY OF THE VYSHNYA RIVER}

The main reason for unsatisfactory quality of natural waters is the pollution of surface water by discharges of untreated sewage and insufficiently treated return waters. Small rivers are the most sensitive to this impact, but they also are the main receivers of return waters from industrial objects. In order to assess the impact of the town of Mostyska waste waters treatment facilities on the Vishnya River, the minimal estimated water flows for the limiting seasons of the year were determined by calculation methods; on the basis of measured morphometric characteristics of the riverbed the velocity of water in the river was calculated; hydro-chemical investigations of the return waters on the outlet from the waste waters treatment plant and the natural waters above and below the outlet have been conducted; for the summer-autumn and winter water means on the basis of the hydro-morphometric characteristics of the riverbed the dilution multiplicity of the return waters by natural waters was calculated; with the employment of the computer program "Hydrosphere" on the basis of mathematical model of the dynamics of the substance concentration in the watercourse the pollutants concentration in the rive calculated cross-section was predicted for the actual discharge in the limiting seasons of the year; in order to determine the assimilation capacity of the river-receiver of return waters the maximum permissible concentrations of pollutants to discharge into the water object during the limiting seasons of the year were calculated. The authors have revealed that the Vyshnya River is capable to assimilate contamination in quantities that several times, and on individual indices dozens of times, exceed the actual discharges. However, by the main pollutant - organics, expressed in BOD, assimilating ability of the river is exhausted completely. Moreover, the actual BOD discharge from Mostyska waste water treatment facilities almost twice exceeds the maximum permissible one. The concentration of BOD in the return waters should be reduced by almost half, which requires optimization of the biochemical treatment stage. ability.

Keywords: outlet; background river cross-section; calculated river cross-section; return waters; dilution multiplicity; assimilating 